\title{
Methods of Risk Management at the Banking Level
}

\author{
Violeta Elena Dragoi \\ adelinanicolescu@yahoo.com \\ Adelina Nicoleta Nicolescu \\ violeta dragoi@yahoo.com \\ Valahia University of Targoviste, România
}

\begin{abstract}
The risk supposed by banks on the market, the most common and the most popular is the interest rate risk. For this reason, each banking institution tries to quantify it in order to be able to monitor it permanently and to take the necessary measures to reduce it. The interest rate risk is generated by the decreasing of commission incomes and of bank earned interests, at the same time with the increase of interest expenses paid over a reference period. The quantification involves the calculation of specific indicators, of which the most common is the spread or GAP.
\end{abstract}

Key words: interest rate risk, bank, sensitive assets and liabilities, maturity bands, GAP

JEL Classification: G210 Banks; depositary; Microfinance Institutions; mortgages E43 Interest rates: determination, structure and effects;

\section{Introduction}

The interest rate risk must be taken into account in order to adopt the measures required to reduce it.

The sensitivity analysis is based on econometric models, simulating different assumptions for raising or lowering the interest rates for each maturity band. The sensitivity is the starting point in analyzing the assets and liabilities of a bank in order to calculate the sensitivity indicator through the GAP model.

Banks are according great importance to the interest rate risk analysis as it influences the amount of net interest income, hence, implicitly, the profitability and market value of their capital.

Although the risk cannot be canceled, it can be limited by the strategies adopted by each bank as a result of analyzing the results obtained by applying the GAP models.

\section{The notion of interest rate risk}

Banking risk is perceived both in terms of losses (reflected in bookkeeping by provisioning) and the additional expenses arising from them, as well as an uncertainty of obtaining a certain profit. The risk attitude of banks is described by the measures adopted by their management, which either lead to the acceptance of a high level of risk in order to obtain a high profit, or take to minimum risks in order to achieve a lower but definite profit. No matter the strategy adopted, the principle of prudence must be fundamental, being imposed by the NBR.

In the context of banking risks, the NBR identifies 5 significant risk categories:

$$
\begin{array}{cl}
\checkmark & \text { Credit risk; } \\
\checkmark & \text { Country risk; } \\
\checkmark & \text { Market risk; } \\
\checkmark & \text { Liquidity risk; } \\
\checkmark & \text { Operational risk; } \\
\checkmark & \text { Reputational risk. }
\end{array}
$$

In the category of market risks, the most important are stated to be:

- Price risk;

- Currency risk; 
- Interest rate risk.

The interest rate risk is defined as the loss resulting from the unfavorable change in market interest rates leading to a decrease in profit. This risk takes two forms:

$\checkmark$ The income risk, representing the failure to achieve the expected level of interest income;

$\checkmark$ The risk of investment, which is the loss of property due to sudden changes in the interest rate.

- Factors favoring interest rate risk are classified into two broad categories:

a) Internal factors (endogenous), which are sub classified into:

$\checkmark$ Strategy of bank;

$\checkmark \quad$ Level and structure of banking assets and liabilities;

$\checkmark$ The size, structure and quality of the loan portfolio.

b) External factors (exogenous), as:

$\checkmark$ Economical environment;

$\checkmark$ Economical, monetary, financial internal economical policy;

$\checkmark$ Lack of correlation between central bank policy and government economical policy.

$\checkmark$ Psychological factors;

$\checkmark$ Interest rate on the interbank market.

\section{The main indicators of interest rate risk are:}

Banks carry out two major categories of operations:

- Active Operations:

$\circ$ lending

O securities

- Passive operations:

$O$ attracting deposits;

o draw securities;

$O$ attracting loans.

During these operations there is a risk of interest rate variation. In order to quantify it, specific indicators are calculated by following steps:

a) Classification of bank assets and liabilities according to the nature of the interest:

- Fixed interest rates;

- Variable interest rates;

Variable interest-bearing assets and liabilities are sensitive to changes in interest rate level. Sensitive assets are not fixe loans and denomination securities. Sensitive liabilities are interestbearing deposits for which variable interest is granted, as well as loans contracted from other banks (including those granted by the central bank).

b) Grouping of maturity sensitive assets and liabilities (by maturity bands);

c) Calculation of differences between sensitive assets and liabilities for each maturity band. This difference is called the difference or GAP, the most important indicator of interest rate risk:

$$
\mathrm{GAP}=\mathrm{A}_{\mathrm{si}}-\mathrm{P}_{\mathrm{si}}
$$

Where $A_{\mathrm{si}}=$ sensitive assets in the maturity band " $\mathrm{i}$ " $\mathrm{P}_{\mathrm{si}}=$ sensitive liabilities in the maturity band " $\mathrm{i}$ "

A second indicator of interest rate risk is the sensitivity index, which is determined by the reporting of assets sensitive to sensitive liabilities:

$$
I_{s}=\frac{A s i}{P_{s i}}
$$

These two indicators reflect the position of the bank. Thus, it can be: 
- Short if GAP $<0$ or Is $<1$, means that the volume of sensitive assets is lower than that of sensitive liabilities, unfavorable situation with the rising interest rate trend;

- Long, if GAP> 0 or Is $>1$, means that the volume of sensitive assets is higher than that of sensitive liabilities, unfavorable situation in the declining trend of the interest rate;

- Neutral, if GAP $=0$ or Is $=1$, means that the volume of sensitive assets is equal to that of sensitive liabilities, an optimal situation, ideal without the risk of interest rate risk or having a minimum level.

\section{Methods and models of interest rate risk management}

For the management of interest rate risk, two models are used:

\section{1) GAP Difference Model (Ecart)}

Through this model, the Bank's position, the difference between maturity sensitive assets and liabilities, is the indicator that measures the interest rate risk. By going through the steps listed in the previous paragraph, this difference is known as the ecart or GAP.

This indicator is used to manage the interest rate risk in order to minimize it, but it can also be a speculative instrument that serves to increase the interest income.

To reduce the interest rate risk, the bank may resort to monetary instruments such as option contracts, swap contracts, futures or forward contracts.

The interest rate fluctuation influences the net interest income of the bank due to the following factors:

a) Changes in interest rates on the market;

In the case of a positive GAP, net interest income increases directly in line with interest rates, if interest rates rise and fall if interest rates are lowered.

In the case of a negative GAP, the situation changes so that net interest income decreases when the interest rate rises and increases when the interest rate decreases.

In the case of a zero GAP, constant interest rate changes do not affect net interest income.

b) Change in the interest margin;

The interest margin (the difference between the interest rate on assets and the interest rate on liabilities) directly influences the net interest income, which decreases when the margin decreases.

c) Change in the amount of interest-bearing assets and liabilities;

Net interest income evolves directly in line with the evolution of the volume of interest-bearing assets and liabilities.

d) Structural changes in the portfolio.

Sensitive assets may be increased by increasing the volume of variable interest loans or by reducing the maturity of investments in securities. Sensitive liabilities may be decreased by reducing long-term investments in favor of deposits with other short-term banks or overnight deposits.

The effectiveness of using the GAP method of difference (Ecart) depends on the number and the timing of the maturity bands, which describe the more accurately the reality as they are shorter and more.

For the entire portfolio, the cumulative GAP is calculated, which gives an overview of the impact of the interest rate risk on the bank.

The result obtained serves to make decisions by the bank's management to maximize profit (subject to the acceptance of a high level of risk) or to minimize risk (in the case of a prudent approach in relation to the assumed risk).

The bank can thus determine an optimal portfolio structure to give it a maximum return on interest. 


\section{2) GAP Duration Model}

Based on the shortcomings in the use of the GAP difference model (the difficulty of setting maturity ranges, the sensitivity of assets and liabilities affected by interest rate changes), the GAP duration model was developed. It consists in calculating the duration of recovery of each asset or liability in relation to the recovery period of the entire portfolio of the bank.

The model starts from the assumption that the discrepancy between the inputs and outputs of assets and liabilities leads to changes in interest rates and, implicitly, to the risk of interest rate risk. The GAP duration method involves setting a bank target in managing the differences between asset average and liability.

The GAP Duration Indicator (DGAP) is calculated by performing the following steps:

a) Calculate the average durations, representing the sum of the assets and liabilities' duration and their weight in the total assets, respectively liabilities (DAi and $\mathrm{DPi})$ :

$$
\mathrm{DA}_{\mathrm{i}}=\sum d A i * p A i
$$

Where: $\mathrm{DAi}=$ the sum of the products' duration of each asset and its weight in the total assets;

$$
\begin{aligned}
& \mathrm{dAi}=\text { asset } " \mathrm{i} \text { " recovery time } \\
& \mathrm{pAi}=\text { the weight of the asset } \mathrm{i} " \text { in the total assets. }
\end{aligned}
$$

$$
\mathrm{DP}_{\mathrm{i}}=\sum d P i * p P i
$$

Where: $\quad \mathrm{DPi}=$ the sum of the products' duration of each liability and its weight in the total liabilities;

$$
\begin{aligned}
& \mathrm{dPi}=\text { duration recovery of liability " } \mathrm{i} \text { " } \\
& \mathrm{pPi}=\text { the share of the "i" liability in the total liabilities. }
\end{aligned}
$$

b) Calculate the ratio between total liabilities and total assets (u);

$$
\mathrm{u}=\frac{T P}{T A}
$$

Where: $\quad \mathrm{u}=$ ratio between total liabilities and total assets

$\mathrm{TP}=$ total liabilities;

$\mathrm{TA}=$ total assets

c) Calculate the DGAP indicator:

$$
\operatorname{DGAP}_{\mathrm{i}}=\mathrm{DA}_{\mathrm{i}}-\mathrm{u} * \mathrm{DP}_{\mathrm{i}}
$$

The analysis of the results obtained will describe the following possible outcomes:

$>$ DGAP> 0 means that the change in the interest rate influences reversed the market value of the bank's capital, which decreases when the interest rate rises and increases when the interest rate decreases.

$>$ DGAP $<0$ indicates a directly proportional change in the bank's market value relative to the change in the interest rate, namely the value increases when interest rises and falls when interest rises.

$>$ DGAP $=0$ indicates the bank's portfolio's independence from changes in interest rates.

Analogue to the cumulative GAP calculation, in the case of the GAP Difference model, to provide an overview of the impact of interest rate risk on the entire portfolio of assets and liabilities of the Bank, is calculated by the ED:

$$
\mathrm{ED}=\frac{D A * A-D P * P}{A-P}
$$

Where:

$$
\begin{aligned}
& \mathrm{DA}=\text { average asset duration; } \\
& \mathrm{DP}=\text { average duration of liabilities; } \\
& \mathrm{A}=\text { total assets; } \\
& \mathrm{P}=\text { total liabilities }
\end{aligned}
$$

The analysis of the results obtained serves to determine the bank's strategy to correct the negative effects, but also to exploit the investment opportunities. 
The decisions adopted are determined by the bank's attitude towards risk. Thus, prudential policy will dictate the adoption of measures that minimize the risk of interest rate so that the long-term spread tends to zero. A policy aimed at maximizing profits will adapt its measures according to the outcome of the long-term (positive or negative) spread, assuming its investment risks.

\section{Instruments used to cover the interest of the rate risk}

The bank derivatives are used to protect the bank from interest rate risk. They do not engage its inheritance except the case of the risk. The principle that underlies the use of these instruments is the agreement of an insurance contract which involves the payment of a risk premium by the beneficiary and the bank undertakes this risk and assumes the liability provided in the clauses of that contract.

The derivatives refer to the following types of off-balance transactions:

\section{a) The SWAP interest;}

The SWAP interest rate operations involve the replacement of fixed rate payments to variable rate payments. The two constituents of the swap agreement agree that one of them makes regular fixed payments to the other, while the other agrees to make variable payments based on a shortterm interest rate index. The payments are made with a gap. For example, the first payment will be made after 6 months, based on the interest rate index. The amount of the second payment, after another 6 months, is determined by the basis of the interest rate index calculated for a half a year ago. Thus the parties involved know the level of the next payment.

\section{b) Forward rate agreements;}

The Forward Rate Agreement involves an agreement between two constituents on a loan with an interest rate set at the beginning. The contract will have some effects in the future, the liquidation date taking place earlier than the due date. Then will be paid the difference calculated a day before between the original interest rate and the market interest rate. The purchase and the sale price quotations take into account the risk of countertrade, the contract being irreversible. The employment periods are set at 3, 6, 9 or 12 months.

The Forward Rate agreements are used for arbitrage, hedging, or speculation.

\section{c) The interest-limiting contracts}

The interest-limiting contracts are concluded to protect borrowers or creditors from adverse effects of interest rate developments in the case of long-term credits.

The contract proposes a half-year payment of an extra pay by the buyer, while the seller will cover the same limits over the same period.

Thus, the borrower will pay a minimum credit cost, while the creditor will maximize the interest income.

\section{The addressing of interest rate risk by the major banks in Romania}

The approach of the interest rate risk has as a central pillar the sensitivity analysis for each of the top five banks in Romania (BCR, BRD, Banca Transilvania, Raiffeisen Bank and UniCredit), all of them are giving a particular importance to the bank risk management.

$\underline{B C \boldsymbol{R}}$ is one of the five banks which is detached from the other four banks by applying no less than 4 methods of measuring the interest rate risk:

$>$ Sensitivity indicators for the market value of certain portfolios;

$>$ Economic value indicators of measuring the evolution of market value in the context of various scenarios;

$>$ Measurement of risk gains to observe the dynamics of operating income in various scenarios;

Risk indicators used for the allocation of economic capital.

The strategies applied in the interest rate risk management related to risk tolerance are based on the forecast of medium to long-term interest rate and business developments. 
From the annual financial statements presented by each of the other 4 banks, $\boldsymbol{B R} \boldsymbol{D}$, Transilvania Bank, Raiffeisen Bank and UniCredit, the main method used to manage the rate risk interest is the sensitivity analysis by calculating gaps using the GAP Model.

The assumptions and the differences between the rate risk interest approaches consist on the determination of sensitive assets and liabilities to be taken into account but also in time ranges in the maturity bands as reflected in the following tables:

The sensitive assets valued by the four banks

- Table no.1-

\begin{tabular}{|c|c|c|c|c|}
\hline Sensitive assets & BRD & $\begin{array}{c}\text { Banca } \\
\text { Transilvania }\end{array}$ & $\begin{array}{c}\text { Raiffeisen } \\
\text { Bank }\end{array}$ & UniCredit \\
\hline -Availability & $\mathrm{x}$ & $\mathrm{x}$ & $\mathrm{x}$ & $\mathrm{x}$ \\
\hline -Bonds on the Central Bank; & $\mathrm{x}$ & $\mathrm{x}$ & $\mathrm{x}$ & \\
\hline -Bonds on financial institutions & $\mathrm{x}$ & $\mathrm{x}$ & $\mathrm{x}$ & $\mathrm{x}$ \\
\hline - Derivatives and Transaction Titles; & $\mathrm{x}$ & & $\mathrm{x}$ & $\mathrm{x}$ \\
\hline -Credit and advances to customers & $\mathrm{x}$ & $\mathrm{x}$ & $\mathrm{x}$ & $\mathrm{x}$ \\
\hline -Receivables of financial leasing & $\mathrm{x}$ & & & \\
\hline - Financial assets available for sale & $\mathrm{x}$ & & & \\
\hline $\begin{array}{l}\text {-Investments in associates and } \\
\text { subsidiaries }\end{array}$ & $\mathrm{x}$ & & & \\
\hline -Commercial Fund & $\mathrm{x}$ & & & \\
\hline -Deferred tax active & $\mathrm{x}$ & & & \\
\hline - Fixed assets and other assets & $\mathrm{x}$ & $\mathrm{x}$ & & $\mathrm{x}$ \\
\hline $\begin{array}{l}\text { - Derivative financial assets designated } \\
\text { as hedging instruments }\end{array}$ & & & & $\mathrm{x}$ \\
\hline $\begin{array}{l}\text { - Financial assets held at fair value in the } \\
\text { profit and loss account; }\end{array}$ & & & & $\mathrm{x}$ \\
\hline
\end{tabular}

Source: Notes to the consolidated and individual financial statements as of 31.12.2017 presented by the four mentioned banks: BRD, Transylvania Bank, Raiffeisen Bank and UniCredit Bank.

As can be seen, the available funds, the receivables on financial institutions and the loans and advances to customers are the categories of sensitive assets taken into account on the risk-ofinterest rate by all four analyzed banks.

Sensitive liabilities valued by the four banks

-Table no.2-

\begin{tabular}{|l|l|l|l|l|}
\hline \multicolumn{1}{|c|}{ Sensitive liabilities } & \multicolumn{1}{|c|}{ BRD } & \multicolumn{1}{c|}{$\begin{array}{c}\text { Banca } \\
\text { Transilvania }\end{array}$} & $\begin{array}{c}\text { Raiffeisen } \\
\text { Bank }\end{array}$ & UniCredit \\
\hline Interbank deposits & $\mathrm{x}$ & $\mathrm{x}$ & $\mathrm{x}$ & $\mathrm{x}$ \\
\hline Customer deposits & $\mathrm{x}$ & $\mathrm{x}$ & $\mathrm{x}$ & $\mathrm{x}$ \\
\hline Loans attracted & $\mathrm{x}$ & $\mathrm{x}$ & $\mathrm{x}$ & $\mathrm{x}$ \\
\hline Subordinated debt & $\mathrm{x}$ & $\mathrm{x}$ & $\mathrm{x}$ & \\
\hline Financial derivatives & $\mathrm{x}$ & & & \\
\hline Issued bonds; & & $\mathrm{x}$ & $\mathrm{x}$ & $\mathrm{x}$ \\
\hline Current tax debt & $\mathrm{x}$ & & & \\
\hline Deferred tax debt & $\mathrm{x}$ & & & $\mathrm{x}$ \\
\hline Other financial liabilities & $\mathrm{x}$ & $\mathrm{x}$ & $\mathrm{x}$ \\
\hline $\begin{array}{l}\text { Financial liabilities held at fair value } \\
\text { through profit or loss; }\end{array}$ & & & & $\mathrm{x}$ \\
\hline $\begin{array}{l}\text { Derivative financial liabilities designated } \\
\text { as hedging instrument }\end{array}$ & & & & \\
\hline
\end{tabular}

Source: Notes at the financial statements consolidated and individual at ${ }^{31 s t}$ of December .2017 presented by the four mentioned banks: BRD, Banca Transylvania Bank, Raiffeisen Bank and UniCredit Bank. 
The table shows that interbank deposits, customer deposits and borrowed loans are the sensitive liability categories used in the quantification of interest rate risk by the four banks mentioned.

Maturity bands considered by the 4 banks -Table no.3 -

\begin{tabular}{|l|l|l|l|l|l|l|}
\hline $\begin{array}{l}\text { Nr. } \\
\text { crt. }\end{array}$ & \multicolumn{1}{|c|}{$\begin{array}{c}\text { The banks } \\
\text { name }\end{array}$} & \multicolumn{5}{|c|}{ Maturity bands } \\
\hline 1 & BRD - GSG & $0-1$ month & $1-3$ months & $3-12$ months & $1-5$ years & $\begin{array}{l}\text { Over } \\
\text { years }\end{array}$ \\
\hline 2 & $\begin{array}{l}\text { Transylvania } \\
\text { Bank }\end{array}$ & $0-6$ months & $6-12$ months & $1-3$ years & $3-5$ years & $\begin{array}{l}\text { Over } \\
\text { years }\end{array}$ \\
\hline 3 & Raiffeisen Bank & $0-3$ months & $3-12$ months & $1-5$ years & Over 5 years & - \\
\hline 4 & UniCredit & $0-3$ months & $3-12$ months & $1-5$ years & Over 5 years & - \\
\hline
\end{tabular}

Source: Notes at the financial statements consolidated and individual at $31^{\text {st }}$ of December 2017 presented by the four mentioned banks: BRD, Transylvania Bank, Raiffeisen Bank and UniCredit Bank.

The maturity band common to all 4 banks corresponds to the timeframe over 5 years. Based on the data gathered from the annual financial statements of 2017, the GAP for each maturity band as well as the sensitivity index for each individual bank can be determined:

Indicators calculation for $B R D$

- Table no.4-

\begin{tabular}{|l|l|l|l|l|l|}
\hline \multicolumn{1}{|c|}{ Indicators } & \multicolumn{1}{|c|}{$\mathbf{0 - 1}$ month } & $\mathbf{1 - 3}$ months & $\mathbf{3 - 1 2}$ months & \multicolumn{1}{|c|}{$\mathbf{1 - 5}$ years } & \multicolumn{1}{c|}{$\begin{array}{c}\text { Over 5 } \\
\text { years }\end{array}$} \\
\hline Total assets & 14974914 & 12459356 & 6700189 & 11362652 & 6304622 \\
\hline Total liabilities & 14959958 & 8242022 & 11469275 & 10850350 & 7219223 \\
\hline $\begin{array}{l}\text { GAP (Net Bank } \\
\text { Position) }\end{array}$ & 14956 & 4217334 & -4769086 & 512302 & -914601 \\
\hline Sensitivity index & 1.000999735 & 1.511686817 & 0.584185923 & 1.047215251 & 0.873310327 \\
\hline
\end{tabular}

Source: Notes at the financial statements consolidated and individual at $31^{\text {st }}$ of December 2017 presented by the four mentioned banks: BRD, Banca Transilvania, Raiffeisen Bank and UniCredit Bank.

Indicators calculation for Banca Transilvania - Table no.5-

\begin{tabular}{|l|l|l|l|l|l|}
\hline \multicolumn{1}{|c|}{ Indicators } & $\mathbf{0 - 6}$ months & \multicolumn{1}{|c|}{$\mathbf{6 - 1 2}$ months } & \multicolumn{1}{|c|}{$\mathbf{1 - 3}$ years } & \multicolumn{1}{|c|}{$\mathbf{3 - 5}$ years } & $\begin{array}{c}\text { Over 5 } \\
\text { years }\end{array}$ \\
\hline Total assets & 37645006 & 1674141 & 1305094 & 711579 & 518203 \\
\hline Total liabilities & 43875552 & 7355049 & 1683574 & 92582 & 135682 \\
\hline $\begin{array}{l}\text { GAP (Net Bank } \\
\text { Position) }\end{array}$ & -6230546 & -5680908 & -378480 & 618997 & 382521 \\
\hline Sensitivity index & 0.85799504 & 0.227618 & 0.7751925 & 7.6859325 & $\begin{array}{l}3.819246 \\
47\end{array}$ \\
\hline
\end{tabular}

Source: Notes at the financial statements consolidated and individual at $31^{\text {st }}$ of December 2017 presented by the four mentioned banks: BRD, Transylvania Bank, Raiffeisen Bank and UniCredit Bank.

Indicators calculation for Raiffeisen Bank

\begin{tabular}{|l|l|l|l|l|}
\hline \multicolumn{1}{|c|}{ Indicators } & $\mathbf{0 - 3}$ months & $\mathbf{3 - 1 2}$ months & \multicolumn{1}{|c|}{$\mathbf{1 - 5}$ years } & \multicolumn{1}{c|}{$\begin{array}{c}\text { Over 5 } \\
\text { years }\end{array}$} \\
\hline Total assets & 22232697 & 5985721 & 4626882 & 273216 \\
\hline Total liabilities & 16992271 & 5927408 & 8922381 & 8817 \\
\hline
\end{tabular}


International Conference "Risk in Contemporary Economy" ISSN-L 2067-0532 ISSN online 2344-5386

$\mathrm{XX}^{\text {th }}$ Edition, 2019, Galati, Romania,

"Dunarea de Jos" University of Galati, Romania - Faculty of Economics and Business Administration

\begin{tabular}{|l|l|l|l|l|}
\hline \multicolumn{1}{|c|}{ Indicators } & $\mathbf{0 - 3}$ months & $\mathbf{3 - 1 2}$ months & \multicolumn{1}{|c|}{$\mathbf{1 - 5}$ years } & \multicolumn{1}{c|}{$\begin{array}{c}\text { Over 5 } \\
\text { years }\end{array}$} \\
\hline GAP (Net Bank Position) & 5240426 & 58313 & -4295499 & 264399 \\
\hline Sensitivity index & 1.308400566 & 1.009838 & 0.5185703 & 30.987411 \\
\hline
\end{tabular}

Source: Notes at the financial statements consolidated and individual at $31^{\text {st }}$ of December 2017 presented by the four mentioned banks: BRD, Transylvania Bank, Raiffeisen Bank and UniCredit Bank.

Indicators calculation for UniCredit

- Table no.7-

\begin{tabular}{|l|l|l|l|l|}
\hline \multicolumn{1}{|c|}{ Indicatori } & $\mathbf{0 - 3}$ months & $\mathbf{3 - 1 2}$ months & \multicolumn{1}{|c|}{$\mathbf{1 - 5}$ years } & \multicolumn{1}{c|}{$\begin{array}{c}\text { Over 5 } \\
\text { years }\end{array}$} \\
\hline Total assets & 29328977 & 1928305 & 4481481 & 1306665 \\
\hline Total liabilities & 31496456 & 1698781 & 500466 & 261887 \\
\hline GAP (Net Bank Position) & -2167478 & 229524 & 3981015 & 1044778 \\
\hline Sensitivity index & 0.931183421 & 1.135111 & 8.9546159 & 4.9894228 \\
\hline
\end{tabular}

Source: Notes at the financial statements consolidated and individual at 31 $31^{\text {st }}$ of December 2017 presented by the four mentioned banks: BRD, Transylvania Bank, Raiffeisen Bank and UniCredit Bank obtained:

By centralizing the data contained in the four tables above, the following information is Centralization of GAP indicator and sensitivity index - Table no.8-

\begin{tabular}{|l|l|l|l|l|}
\hline & \multicolumn{1}{|c|}{ BRD } & \multicolumn{1}{|c|}{$\begin{array}{c}\text { Banca } \\
\text { Transilvania }\end{array}$} & Raiffeisen Bank & \multicolumn{1}{|c|}{ UniCredit } \\
\hline $\begin{array}{l}\text { GAP }>0 \text { and } \\
\text { Is }>1\end{array}$ & $\begin{array}{l}0-1 \text { month } \\
1-3 \text { months } \\
1-5 \text { years }\end{array}$ & $\begin{array}{l}\text { 3-5 years } \\
\text { Over 5 years }\end{array}$ & $\begin{array}{l}\text { 0-3 months } \\
3-12 \text { months } \\
\text { Over 5 years }\end{array}$ & $\begin{array}{l}\text { 3-12 months } \\
1-5 \text { years } \\
\text { Over 5 years }\end{array}$ \\
\hline $\begin{array}{l}\text { GAP }<0 \text { and } \\
\text { Is }<1\end{array}$ & $\begin{array}{l}\text { 3-12 months } \\
\text { Over 5 years }\end{array}$ & $\begin{array}{l}\text { 0-6 months } \\
\text { 6-12 months } \\
1-3 \text { years }\end{array}$ & 1-5 years & $0-3$ years \\
\hline
\end{tabular}

Source: Notes at the financial statements consolidated and individual at $31^{\text {st }}$ of December 2017 presented by the four mentioned banks: BRD, Transylvania Bank, Raiffeisen Bank and UniCredit Bank

The positive GAP indicator or the sensitivity index $>1$ reflects a favorable situation of the bank in the event of the market interest rate hike, or unfavorable in the case of the downward trend in interest rates.

At the same time, the GAP $<0$ and the sensitivity index $<1$ indicate an unfavorable situation in the case of the trend of increasing market interest rates, which is favorable in the case of the decrease of the interest rates.

If for BRD and Raiffeisen Bank we have a positive GAP for the first maturity bands, for Transylvania Bank and UniCredit, the first maturity bands bring a negative GAP.

At the same time, for longer-term maturity bands (Raiffeisen Bank), respectively more than 5 years (BRD), GAP> 0 and Is $>1$, and for Transylvania Bank and UniCredit, for the first maturity bands GAP $<0$ and Is $<1$.

\section{Conclusions}

In the case of BCR, BRD, Transylvania Bank, Raiffeisen Bank and UniCredit Bank, the interest rate risk is managed by monitoring the spread (GAP) for different stress scenarios and by imposing a predetermined system of limits for each of the interest rate bands. This analyzes this risk both on the economic side and on the volatility of net interest income. 
The compliance with these limits is achieved by the Asset and Liability Management Committee (ALCO), assisted by the risk management department (Risk Management or Treasury Department).

The reduction in the interest rate risk is achieved through the use of derivative financial instruments, mainly swaps, whereby banks undertake to exchange with third parties the difference between the fixed rate and another variable over a certain period of time.

Higher sensitivity indices for maturity bands over a one-year maturity band give banks the necessary response to adopting policies and strategies to adjust to financial market conditions.

In the consolidated and individual financial statements at $31^{\text {st }}$ of December 2017, the management of each bank mentions that the assumed risk limits, the policies adopted leading to the balance between the attainment of the performance targets and the low tolerance towards the interest rate risk were respected.

\section{References}

1) Prof. univ. Leonardo Badea - Banking Risk Management Course

2) Susana Iosof and Teodor Gavri - "Risk Management" - Prouniversitaria Publishing House, Bucharest 2013;

3) Conf. Univ. dr. Constantin Anghelache, Lecturer Ph.D. Marian Sfetcu - "The model for analyzing the sensitivity of the bank's risk indicators to the interest rate variation" - Romanian Statistics Magazine Supplement no. 12/2017;

4) Website mmm.scritub.com - "Interest Rate Risk"

5) The website wnw.creeaza.com - "Interest rate risk and management methods"

6) BCR - "Notes to the Consolidated and Separate Financial Statements for the Year Ended 31 December $2017^{\prime \prime}$

7) BRD - Groupe Société Générale S.A. - "Consolidated and individual financial statements for the year 2017"

8) Banca Transilvania SA - "Notes to Consolidated and Separate Financial Statements" at 31.12.2017

9) Raiffeisen Bank SA - "Notes to the Consolidated and Separate Financial Statements for the Year Ended 31 December 2017"

10) UniCredit Bank $S A$ - "Notes to the separate financial statements for the year ended 31 December 2017" 